\title{
Resistant and susceptible tomato genotypes have direct and indirect effects on Podisus nigrispinus preying on Tuta absoluta larvae
}

\author{
Daline Benites Bottega ${ }^{a}$, Bruno Henrique Sardinha de Souza ${ }^{b, *}$, Nara Elisa Lobato Rodrigues ${ }^{c}$, \\ Wellington Ivo Eduardo ${ }^{c}$, José Carlos Barbosa ${ }^{c}$, Arlindo Leal Boiça Júnior ${ }^{c}$ \\ ${ }^{a}$ Federal Institute of Education, Science and Technology of Goiás (IFG), Campus Iporá, Avenida Oeste, Saída para Piranhas, 76200-000 Iporá, State of Goiás, Brazil \\ ${ }^{\mathrm{b}}$ The University of Lavras (UFLA), Campus Universitário, 37200-000 Lavras, State of Minas Gerais, Brazil

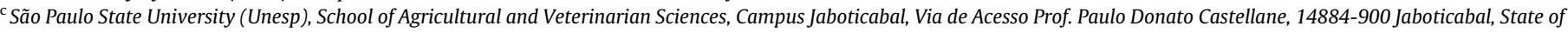 \\ São Paulo, Brazil
}

\section{H I G H L I G H T S}

- Resistant plant genotypes may affect natural enemies directly and indirectly.

- Resistant tomato plants directly affected $P$. nigrispinus development and behavior.

- The negative effects were associated with density and types of glandular trichomes.

- Using P. nigrispinus and resistant tomato could be antagonistic for $T$. absoluta control.

\section{A R T I C L E I N F O}

\section{Article history:}

Received 14 September 2016

Revised 19 December 2016

Accepted 20 December 2016

Available online 21 December 2016

\section{Keywords:}

Biological control

Glandular trichomes

Predatory stink bug

Tomato leafminer

Tritrophic interaction

\section{G R A P H I C A L A B S T R A C T}

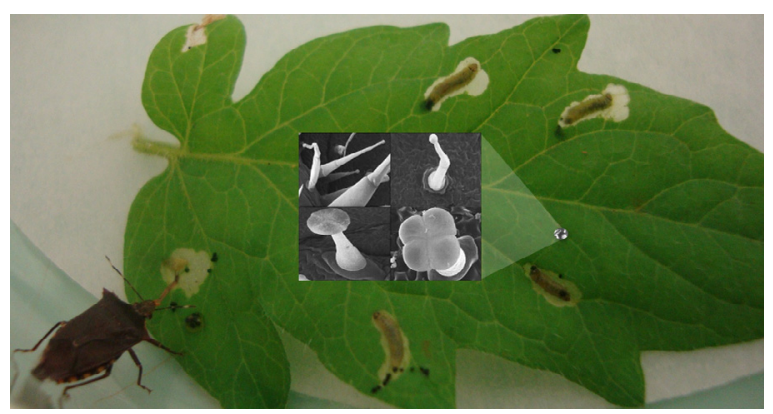

\begin{abstract}
A B S T R A C T
Studies that focus on understanding complex interactions among resistant plants, herbivores, and their natural enemies are fundamental to elucidating whether plant herbivore defenses impose beneficial, adverse, or neutral effects on natural enemies. The impacts of resistant plant genotypes on natural enemies can determine the feasibility of integrating host plant resistance with biological control in IPM programs. We investigated direct and indirect effects of tomato trichomes on the predatory stink bug Podisus nigrispinus by assessing the development, predatory capacity, and foraging behavior of bugs fed Tuta absoluta larvae reared on resistant and susceptible tomato genotypes in both the presence and absence of the plant. We also characterized and quantified glandular leaf trichomes on the tomato genotypes to assess correlations between these and observed effects on the predator. The resistant tomato genotype did not affect $P$. nigrispinus development in the absence of the plant, but survival, adult longevity, number of larval prey consumed, and foraging behavior were all negatively impacted in the presence of resistant plants. These negative effects on P. nigrispinus were associated with higher densities of type I and type IV glandular leaf trichomes on resistant plants compared to susceptible ones. We infer that resistant genotypes possessing high densities of glandular trichomes, especially those of type I and IV, could be antagonistic to biological control of T. absoluta by P. nigrispinus in tomato fields. Additional research is warranted to assess other effective and environmentally safe control methods for integration with P. nigrispinus biological control in tomato IPM.
\end{abstract}

(c) 2016 Elsevier Inc. All rights reserved.

\footnotetext{
* Corresponding author.

E-mail addresses: daline.bottega@ifgoiano.edu.br (D.B. Bottega), souzabhs@gmail.com (Bruno Henrique Sardinha de Souza), naraelr@gmail.com (N.E.L. Rodrigues), wellington_ie@hotmail.com (W.I. Eduardo), jcbarbosa@fcav.unesp.br (J.C. Barbosa), aboicajr@fcav.unesp.br (A.L. Boiça Júnior).
} 


\section{Introduction}

The tomato leafminer, Tuta absoluta (Meyrick) (Lepidoptera: Gelechiidae), has long been considered one of the major pests of tomatoes, Solanum lycopersicon L., in South America. It has also become a major threat to tomato production in Europe, Africa, and Eurasia after its recent introduction to these regions (Desneux et al., 2010, 2011; Galdino et al., 2015). Larvae of T. absoluta can injure both the leaves and fruits of tomatoes, ultimately leading to reductions in yield (Desneux et al., 2011; Tropea Garzia et al., 2012; Galdino et al., 2015). Nigeria, for instance, recently reported losses of about US\$ 3.5 million caused by T. absoluta (Opara, 2016). In order to mitigate losses, insecticides have been heavily applied to tomatoes (Siqueira et al., 2000). However, chemical control has not been completely effective and a number of problems have arisen from frequent applications, especially the evolution of insecticide-resistant $T$. absoluta populations (Siqueira et al., 2001; Silva et al., 2011; Roditakis et al., 2015) as well as detrimental impacts on natural enemies (Gentz et al., 2010; Biondi et al., 2013; Abbes et al., 2015).

There has been much effort in recent years to integrate multiple control tactics in crop pest management programs. Many studies have focused on understanding tritrophic interactions among plants, herbivores, and their natural enemies (Zanuncio et al., 2012; Bottega et al., 2014; Jesus et al., 2014; Pérez-Hedo et al., 2015; Naselli et al., 2016). Understanding the behavioral and ecological roles of natural enemies in complex multitrophic interactions with herbivores and plants is of great importance for effective use of natural enemies in IPM programs.

Various species of Asopinae stink bugs (Heteroptera: Pentatomidae) have proven promising as biological control agents of insect pests (Molina-Rugama et al., 1997; Vivan et al., 2002). Stink bugs of the genus Podisus are generalist predators found in various ecosystems that prey preferentially on lepidopterous larvae (De Bortoli et al., 2011; Vacari et al., 2012). In Brazil, Podisus nigrispinus (Dallas) preys on a variety of insect pests infesting numerous crops, including pests of tomatoes such as tomato leafminer (De Clercq, 2000). P. nigrispinus has demonstrated great potential for preying on T. absoluta larvae in the laboratory (Vivan et al., 2002), and therefore this predator can be regarded as a potential biocontrol agent of T. absoluta in tomato IPM, especially in European, African, and Eurasian countries where the pest is recently invasive. De Clercq et al. (2000) reported that $P$. nigrispinus feeding behavior varied according to host plant of the prey, and that its functional response to larvae of Spodoptera exigua (Hübner) differed on tomato plants compared to eggplant and sweet pepper.

Host plant resistance can be an important component of IPM programs. Resistant plants can help maintain pest populations below economic injury levels and are usually compatible with other control methods, in addition to being environmentally safe (Smith, 2005). Sources of resistance to several insect pests have been identified in wild tomato species (Baldin et al., 2005; Oliveira et al., 2012; Bottega et al., 2015), and the corresponding genes have been introgressed into commercial cultivars. For example, tomato plants possess glandular trichomes that accumulate metabolites toxic to herbivorous insects (Schilmiller et al., 2008; Weinhold and Balwin, 2011). The wild tomato relative Solanum habrochaites Knapp \& D.M Spooner expresses the allellochemical 2-tridecanone (2-TD) in glandular trichomes, a compound toxic to arthropod pests, including T. absoluta (Maluf et al., 1997; Gonçalves et al., 1998; Oliveira et al., 2012). Since the presence of glandular trichomes can adversely affect insect development, this common resistance trait warrants investigation for possible effects on the predator $P$. nigrispinus.
In view of the possibility of integrating resistant tomato genotypes and biological control against T. absoluta in tomato IPM programs, studies on the plant-herbivore-natural enemy complex are necessary to elucidate whether the effects of defensive traits in resistant tomatoes are beneficial (Ruberson et al., 1986), adverse (Vivan et al., 2003), or neutral (Valicente and O'Neil, 1995) to tomato leafminer natural enemies. Traits that defend plants against herbivory may render pests more susceptible to natural enemies, insectides, and/or abiotic mortality factors. However, resistance traits also may be deleterious to natural enemies. To date, little is known about the interactions among resistant tomatoes, the tomato leafminer, and predatory stink bugs, interactions that should be carefully examined prior to use $P$. nigrispinus as a biocontrol agent.

In this study, we investigated tritrophic interactions among genotypes of tomatoes, $T$. absoluta, and $P$. nigrispinus by assessing the development, predatory capacity, and foraging behavior of the bug on $T$. absoluta larvae reared on resistant and susceptible tomato genotypes. In addition, we characterized and quantified glandular trichomes on leaves of the resistant and susceptible tomato genotypes and correlated their presence with effects on P. nigrispinus.

\section{Materials and methods}

\subsection{Experimental conditions}

Experiments were carried out at the Department of Crop Protection, São Paulo State University (Unesp), School of Agricultural and Veterinarian Sciences, Campus Jaboticabal, in Jaboticabal county, state of São Paulo, Brazil. Insect rearing and all laboratory experiments and bioassays were conducted in a climate-controlled room set to $25 \pm 1{ }^{\circ} \mathrm{C}, 70 \pm 10 \% \mathrm{RH}$, and 12:12 L:D photoperiod (J. Prolab, São José dos Pinhais, PR, Brazil). Assays to evaluate behavior of the predator on resistant and susceptible plants and reductions of $T$. absoluta injury in the presence or absence of the biocontrol agent were conducted in a greenhouse. under ambient temperature, humidity, and lighting $\left(23-35^{\circ} \mathrm{C}, 55-72 \% \mathrm{RH}\right.$, and $\sim 14: 10 \mathrm{~L}: \mathrm{D}$ photoperiod).

\subsection{Plants}

Two tomato genotypes were used in assays: PI 134417 of the wild species $S$. habrochaites, (resistant genotype) and the commercial S. lycopersicum cultivar Santa Clara (susceptible genotype). These genotypes were previously screened for resistance to T. absoluta and classified as moderately antibiotic and highly susceptible, respectively (Bottega et al., 2015). Seeds of both plants were sown in polystyrene cell trays filled with commercial potting mixture and seedlings were transplanted into 3-L-plastic pots filled with soil, sand, and organic substrate at 3:1:1 ratio $\sim 1$ month after germination. The plants were watered daily and maintained in the greenhouse until use in the assays.

\subsection{Insect rearing}

A colony of $T$. absoluta was maintained in the laboratory on a natural diet of tomato leaves for $\sim 2$ years following the methodology of Miranda et al. (1998). Larvae of T. absoluta were fed on leaves of the tomato cultivar Santa Cruz Kada Paulista, and adults were fed a $10 \%$ honey solution on a piece of cotton wool. A colony of the predator P. nigrispinus was reared on larvae of Diatraea saccharalis (F.) that were reared on artificial diet (Hensley and 
Hammond, 1968). P. nigrispinus rearing procedures followed the methodology of Zanuncio et al. (1991).

Initially, $P$. nigrispinus were held as eggs and first instars in Petri dishes ( $9 \mathrm{~cm}$ diameter), 30 individuals per dish, with a piece of moistened cotton wool. Upon molting to the second instar, $P$. nigrispinus were transferred to plastic containers $(15 \mathrm{~cm}$ diam $\times 15 \mathrm{~cm} \mathrm{ht),} 10$ individuals per container, each with a 1 -cm-diam hole cut in the lid to permit insertion of a plastic tube $(0.9 \mathrm{~mm}$ diam $\times 65 \mathrm{~mm} \mathrm{ht}, 2.5 \mathrm{ml}$ vol) filled with distilled water. The open end of tube inside the container was plugged with cotton wool to provide hydration for the bugs. Larvae of $D$. saccharalis were offered ad libitum on a daily basis. Eggs laid by P. nigrispinus were carefully removed from the container's walls with a piece of moistened cotton wool and transferred to Petri dishes, two egg masses per dish ( $\sim 15$ eggs per mass).

\subsection{Quantitative and qualitative assessment of tomato glandular trichomes}

Leaves were collected from mid and apical parts of $60 \mathrm{~d}$-old plants of each genotype for characterization and quantification of glandular trichomes. The leaves were pooled, washed in running water, allowed to dry on paper towels at room temperature $\left(\sim 25^{\circ} \mathrm{C}\right)$, and cut in pieces $0.5 \mathrm{~cm}$ square using scissors. The leaf pieces were fixed with $3 \%$ glutaraldehyde in $0.05 \mathrm{M}$ phosphate buffer ( $\mathrm{pH} 7.4$ ), at $8{ }^{\circ} \mathrm{C}$ for $72 \mathrm{~h}$. The leaf material was washed six times with pure buffer every $15 \mathrm{~min}$, post-fixed in $2 \%$ osmium tetroxide, dehydrated in a gradient ethanol series $(30,50,70,80,90,95,100$, 100 , and $100 \%$ ) every $15 \mathrm{~min}$, and then dried in a critical point dryer using $\mathrm{CO}_{2}$. The leaf material was then metalized with $35 \mathrm{~nm}$ gold palladium in a sputter (Dentom Vacuum Desk II, Dentom Vacuum LLC, Moorestown, NJ, USA) and micrographed under a scanning electron microscope (JEOL JSM 510, JEOL, Freising, Germany) at $15 \mathrm{kV}$ (Luckwill, 1943). Glandular trichomes were characterized and counted on the abaxial and adaxial leaf surfaces within a $0.038-\mathrm{cm}^{2}$ area under the scanning electron microscope (50x magnification). Glandular leaf trichomes were characterized based on the criteria of Aragão et al. (2000a). The number of glandular trichomes per $0.038 \mathrm{~cm}^{2}$ was converted into the number per $\mathrm{cm}^{2}$. Fifteen replicates were examined for each tomato genotype, each replicate consisting of one leaflet from one plant.

\subsection{Biological performance and predatory capacity of P. nigrispinus}

Plants absent. Preliminary assays revealed that $P$. nigrispinus consumed more $T$. absoluta larvae in the absence of tomato plants than in their presence. Although the absence of any plant is quite artificial, it was necessary to control for any direct plant effects and thus ensure that any effects on P. nigrispinus development were only caused by the T. absoluta larvae. Larvae of $T$. absoluta were reared on either leaves of resistant PI 134417 or susceptible Santa Clara and fed to developing P. nigrispinus in a completely randomized design with 30 replicates per treatment. Each replicate consisted of a cylindrical plastic container $(9.5 \mathrm{~cm}$ diam $\times 9.5 \mathrm{~cm}$ ht) with 10 third-fourth instar T. absoluta larvae and one P. nigrispinus second instar nymph. We recorded the duration of $P$. nigrispinus nymphal instars, nymph-to-adult survival, and the longevity of unfed adults. The predatory capacity of $P$. nigrispinus was assessed as the number of $T$. absoluta larvae consumed in each nymphal instar and over the entire course of nymphal development.

Plants present. In this assay, each replicate consisted of a transparent plastic container $(15 \mathrm{~cm}$ diam $\times 15 \mathrm{~cm} \mathrm{ht})$ containing an excised branch of a $60 \mathrm{~d}$-old tomato plant. The branch was placed in the container through a hole in the bottom and the cut stem placed in a smaller plastic container $(8 \mathrm{~cm}$ diam $\times 8 \mathrm{~cm} \mathrm{ht})$ filled with distilled water to retain plant turgor during the assay. The larger container was covered with a transparent plastic lid, and distilled water was made available to the bugs through a plastic tube $(0.9 \mathrm{~mm}$ diam $\times 65 \mathrm{~mm}$ ht, $2.5 \mathrm{ml}$ vol$)$ plugged with cotton wool and inserted through a hole in the lid.

Each tomato branch was infested with five third-fourth-instar T. absoluta larvae using a fine brush. First and second instar larvae mine the leaves, feeding on the mesophyll, whereas older larvae usually emerge from their mines and search for young apical leaves, stems or fruits on which they complete larval development (Desneux et al., 2011; Galdino et al., 2015). The latter may represent a period of susceptibility to predation by natural enemies in the field. We selected older, rather than younger, leafminer larvae because fewer larvae would be required to feed the predator over the course of the assays.

Three hours after infestation of the branches, one $P$. nigrispinus second-instar nymph was released in each cage with the aid of a fine brush. Assessments of $P$. nigrispinus predatory capacity were made every $24 \mathrm{~h}$, and larvae preyed on were replaced to maintain five larvae in each container. When $P$. nigrispinus nymphs reached adulthood, they were isolated in cylindrical glass tubes $(1.5 \mathrm{~cm}$ diam $\times 9 \mathrm{~cm} \mathrm{ht)}$ with water supplied in a tube as previously described, and their adult longevity recorded.

\subsection{Persistence of $P$. nigrispinus on resistant and susceptible tomato plants infested with T. absoluta larvae}

This assay directly observed the behavior of $P$. nigrispinus nymphs and adults foraging for T. absoluta larvae on either PI 134417 or Santa Clara plants. In each treatment, 15 replicates were used for each biological stage of $P$. nigrispinus. Tomato plants ( $60 \mathrm{~d}$ old, $\mathrm{n}=15$ per treatment) were each infested with 10 larvae of T. absoluta (12 d old) using a fine brush. Each plant was covered with a voile-fabric cage to isolate the replicate and prevent larvae from escaping. Either one $P$. nigrispinus third-instar nymph or one adult female was then released in each cage (replicate). The residence time of bugs on each plant was directly observed and recorded until the predator left the plant.

\subsection{Damage to resistant and susceptible tomatoes by $T$. absoluta larvae and biological control by P. nigrispinus}

A greenhouse assay was conducted to assess plant damage and biological control outcomes when $60 \mathrm{~d}$-old plants were each infested on a middle branch with eight $12 \mathrm{~d}$-old $T$. absoluta larvae (second-third instar) and then caged with either an adult female $P$. nigrispinus, a third instar nymph, or no predator (control). This number of leafminers is sufficient to be consumed by an adult female $P$. nigrispinus in three days (Vivan et al., 2002). The setup yielded a $2 \times 3$ factorial design consisting of three predator treatments ( $n=6$ replications per treatment) repeated on both resistant and susceptible tomato genotypes. The infested branch of each plant was enclosed with a round plastic container $(11 \mathrm{~cm}$ diam $\times 25 \mathrm{~cm} \mathrm{ht}$ ) sealed bottom and top with voile fabric. An elastic band was used to gather the fabric at the top, and a string to tie the base of the cage to the tomato branch. A single predator was released into each cage one $h$ after introduction of the leafminer larvae.

After $72 \mathrm{~h}$, all live T. absoluta larvae were recovered from plants and counted, and the leaf area consumed was measured by means of a leaf area meter (LI-COR, Lincoln, NE, USA). Infested branches were detached from tomato plants and transferred to the laboratory where the consumed patches of leaves were covered with tape, allowing total leaf area of the branch to be determined in $\mathrm{cm}^{2}$. Next, the tape was removed and consumed leaf area was 
estimated. The damaged leaf area was then expressed as a percent of total leaf area.

\subsection{Statistical analysis}

All data were tested for normality and homogeneity of variance and data that failed these tests were either appropriately transformed or analyzed by non-parametric methods. The numbers of glandular trichomes per unit leaf area were analyzed by Student's independent $t$-test $(\alpha=0.05)$. Data on P. nigrispinus development and predatory capacity in plant-absent and plant-present conditions were analyzed by either Student's independent $t$-test or Mann-Whitney's $U$ test ( $\alpha=0.05$ in both cases). Data on the leaf area injured by T. absoluta and the number of surviving larvae were analyzed by two-way ANOVA to detect main effects of genotype, predator stage, and any genotype $\times$ predator stage interaction. Treatment means were compared by Tukey's test $(\alpha=0.05)$ when three groups were compared. Data on $P$. nigrispinus persistence on tomato plants were analyzed by Mann-Whitney's $U$ test $(\alpha=0.05)$. Statistical analysis was performed using SAS 9.0 software (SAS Institute, 2008).

\section{Results}

\subsection{Quantitative and qualitative assessment of tomato glandular trichomes}

The resistant genotype PI 134417 possessed higher densities of glandular trichomes on both abaxial $\left(t_{28}=2.15, P=0.0458\right)$ and adaxial $\left(t_{28}=2.47, P=0.0235\right)$ leaf surfaces than did the susceptible genotype Santa Clara (Table 1). The resistant genotype had 51\% higher density of glandular trichomes on the abaxial surface and $53 \%$ on the adaxial surface compared to the susceptible genotype.

\section{Table 1}

Mean ( \pm SE) numbers of glandular trichomes of different types $\mathrm{cm}^{-2}$ on abaxial and adaxial leaf surfaces of resistant (PI 134417) and susceptible (Santa Clara) tomato plants.

\begin{tabular}{llll}
\hline Plant type & Trichome type & Abaxial $^{\mathrm{a}}$ & Adaxial $^{\mathrm{a}}$ \\
\hline PI 134417 & I, IV, VI, and VII & $836.8 \pm 179.47$ & $539.5 \pm 97.11$ \\
Santa Clara & VI and VII & $407.9 \pm 88.42$ & $255.3 \pm 61.58$ \\
\hline
\end{tabular}

a Treatment means were significantly different (independent $t$-test, $P<0.05$ ).
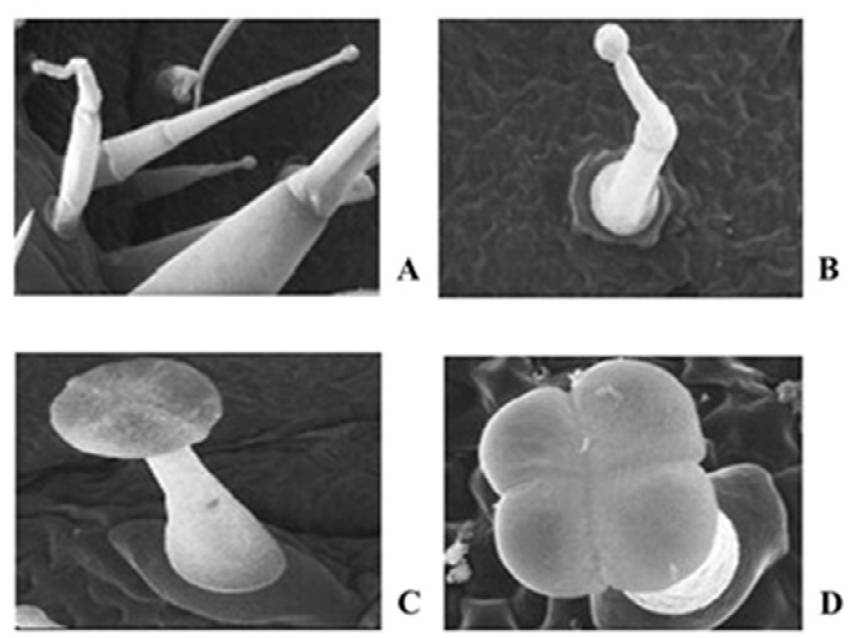

Fig. 1. Glandular trichomes of types I (A), IV (B), VI (C), and VII (D) observed on resistant PI 134417 tomato plants. Only trichome types VI and VII were found on leaves of susceptible Santa Clara plants.
In addition, four types of glandular trichomes were identified on leaves of the resistant genotype, namely types I, IV, VI, and VII, whereas only two types were recorded on leaves of the susceptible genotype, types VI and VII (Fig. 1).

\subsection{Biological performance and predatory capacity of $P$. nigrispinus}

In the presence of plants, there was no effect of tomato genotype on the duration of $P$. nigrispinus second instar $\left(U_{29}=71.0\right.$, $P=0.5500)$, third instar $\left(U_{26}=65.5, P=1\right)$, fourth instar $\left(U_{24}=36.5, P=0.6172\right)$, or fifth instar $\left(t_{21}=0.43, P=0.6688\right)$, or total nymphal development $\left(t_{21}=0.34, P=0.7383\right)$. Shorter adult longevity $\left(t_{21}=5.76, P<0.0001\right)$ was observed when $P$. nigrispinus developed on $T$. absoluta larvae fed on the resistant genotype (Fig. 2A). Similarly, tomato genotype did not affect the duration of $P$. nigrispinus second instar $\left(U_{42}=226.5, P=0.7548\right)$, third instar $\left(U_{42}=223.5, P=0.7017\right)$, fourth instar $\left(U_{38}=176.0, P=0.5565\right)$, or fifth instar $\left(t_{35}=1.93, P=0.0618\right)$, or total nymphal development $\left(U_{35}=126.5, P=0.1805\right)$ when plants were absent (Fig. $\left.2 B\right)$. Shorter adult longevity $\left(U_{24}=24.0, P<0.0001\right)$ was again observed when $P$. nigrispinus developed on larvae of $T$. absoluta fed on leaves of the resistant genotype (Fig. 2B).

Although tomato genotype significantly affected the survival of $P$. nigrispinus when plants were present $\left(U_{21}=225.0, P=0.0008\right)$, survival was not significantly affected by tomato cultivar when $P$. nigrispinus were fed larvae of $T$. absoluta in the absence of the plants $\left(U_{35}=435.0, P=0.8267\right.$ ) (Fig. 3 ).

With plants present, there were significant differences between resistant and susceptible tomatoes in the number of $T$. absoluta larvae consumed by $P$. nigrispinus second instars $\left(U_{19}=10.0\right.$, $P=0.0020)$, fourth instars $\left(t_{15}=5.75, P<0.0001\right)$ and fifth instars $\left(t_{15}=3.06, P<0.0001\right)$, and in the total number of larvae consumed $\left(t_{15}=6.05, P<0.0001\right)$ over the entire period of immature development (Fig. 4A). Consumption of $T$. absoluta larvae by nymphal P. nigrispinus was 2.3-fold greater when prey developed on the susceptible genotype compared to the resistant genotype. However, consumption by third instars did not vary with plant type $\left(U_{16}=18.5, P=0.2433\right)$ (Fig. $\left.4 \mathrm{~A}\right)$.

With plants absent, more $T$. absoluta larvae were consumed by 5 th instars $\left(t_{22}=5.66, P<0.0001\right)$, and more total larvae were consumed over the period of immature development $\left(t_{22}=5.45\right.$, $P<0.0001$ ) when they were reared on the resistant, rather than the susceptible, tomato genotype (Fig. 4B). There were no significant differences in consumption by second instars $\left(t_{22}=0.98\right.$, $P=0.3400)$, third instars $\left(t_{22}=1.50, P=0.1477\right)$ or fourth instars $\left(t_{22}=1.73, P=0.0971\right)$. In contrast to results in the presence of tomato plants, consumption by $P$. nigrispinus nymphs averaged 1.4-fold greater when $T$. absoluta larvae developed on the resistant genotype.

\subsection{Persistence of P. nigrispinus on resistant and susceptible tomato} plants infested with $T$. absoluta larvae

The time that nymphs and adults of $P$. nigrispinus remained on tomato plants was significantly influenced by plant genotype (Table 2). Third instar P. nigrispinus remained on susceptible Santa Clara tomato plants approximately 22 min longer than on PI 134417 plants $\left(U_{28}=55.5, P=0.0181\right)$, whereas adults remained nearly $30 \mathrm{~min}$ longer $\left(U_{28}=41.5, P=0.0030\right)$.

\subsection{Damage to resistant and susceptible tomatoes and biological control by P. nigrispinus}

There was significant interaction between plant genotype and predator life stage for the number of live larvae of $T$. absoluta recovered from plants $\left(F_{2,30}=5.47, P=0.0095\right)$, but the interaction was 

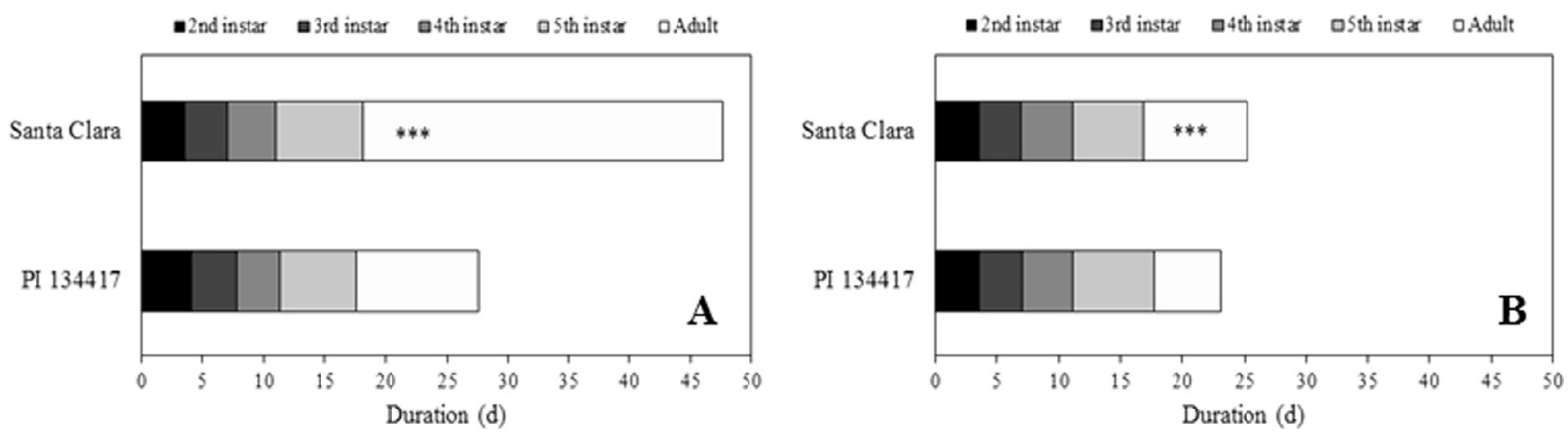

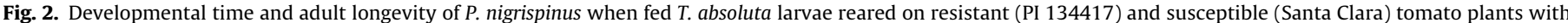
(A) and without (B) plants present. ${ }^{* * *}, P<0.001$.

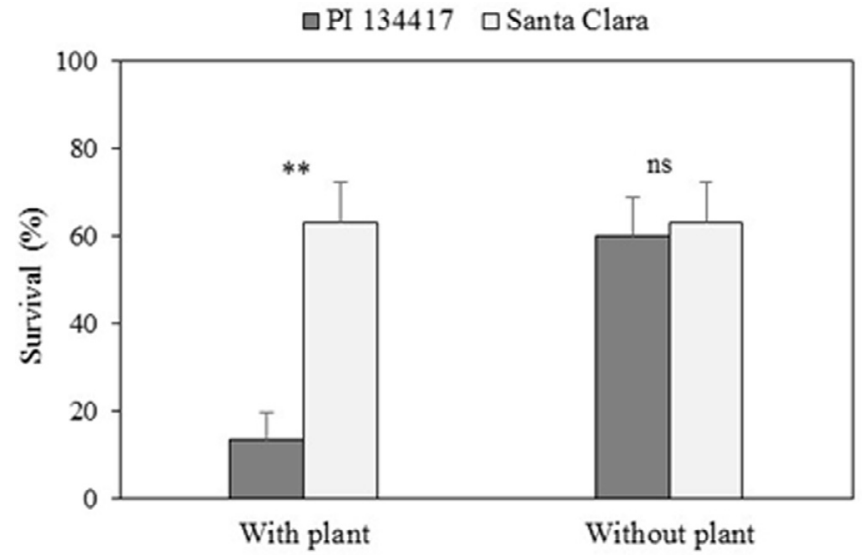

Fig. 3. Survival (to adult stage, percent) of $P$. nigrispinus nymphs fed $T$. absoluta larvae reared on resistant (PI 134417) or susceptible (Santa Clara) tomato plants either with or without the plant present. ${ }^{* *}, P<0.01$.

not significant for leaf area injured by the pest $\left(F_{2,30}=0.24\right.$, $P=0.7903)$. There was no difference between tomato genotypes in either the numbers of live larvae recovered $\left(F_{1,30}=0.44\right.$, $P=0.5124)$ or the leaf area damaged $\left(F_{1,30}=0.84, P=0.3678\right)$.

The life stage of $P$. nigrispinus significantly influenced the number of live larvae recovered from tomato plants $\left(F_{2,30}=95.52\right.$, $P<0.0001$; Fig. 5) and the leaf area damaged by $T$. absoluta larvae $\left(F_{2,30}=3.93, P=0.0305\right)$. The fewest live $T$. absoluta larvae were recovered from susceptible plants when $P$. nigrispinus adults were released, followed by nymphs (Fig. 5). In contrast, similar numbers of live T. absoluta larvae were recovered from resistant plants in
Table 2

Mean $( \pm \mathrm{SE})$ duration of residence by third instar and adult $P$. nigrispinus on resistant (PI 134417) and susceptible (Santa Clara) tomato plants infested with T. absoluta larvae.

\begin{tabular}{lll}
\hline Plant type & \multicolumn{2}{l}{ Time on tomato plants (min, sec) } \\
\cline { 2 - 3 } & Nymphs $^{\mathrm{a}}$ & Adults $^{\mathrm{a}}$ \\
\hline PI 134417 & $15^{\prime} 42^{\prime \prime} \pm 5^{\prime} 35^{\prime \prime}$ & $14^{\prime} 41^{\prime \prime} \pm 5^{\prime} 29^{\prime \prime}$ \\
Santa Clara & $37^{\prime} 43^{\prime \prime} \pm 6^{\prime} 10^{\prime \prime}$ & $43^{\prime} 70^{\prime \prime} \pm 6^{\prime} 30^{\prime \prime}$ \\
\hline
\end{tabular}

${ }^{a}$ Treatment means were significantly different (Mann-Whitney $U$ test, $P<0.05$ ).

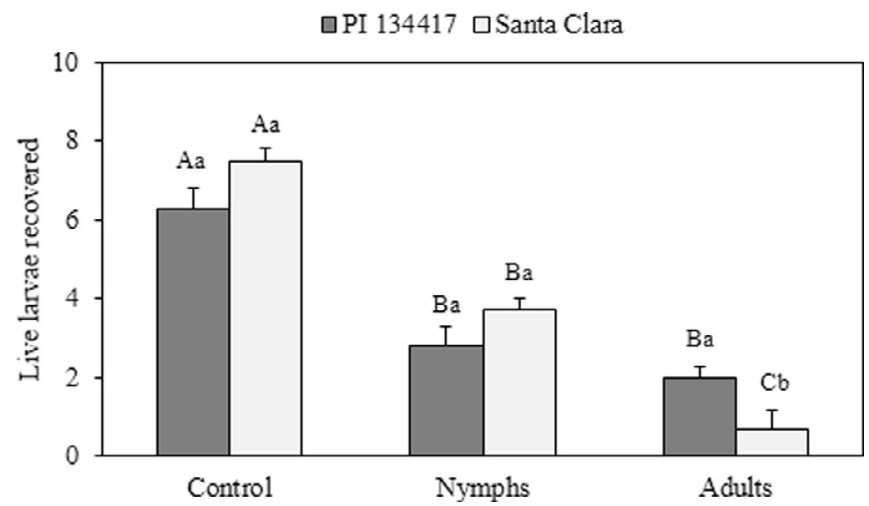

Fig. 5. Means of numbers of live T. absoluta larvae recovered (out of eight infested) from plants of resistant (PI 134417) and susceptible (Santa Clara) tomato plants $72 \mathrm{~h}$ after release of a single $P$. nigrispinus third instar nymph, adult, or control (no predator). Columns bearing different lower-case letters were significantly different $(P<0.05)$ between plant types; columns bearing different upper-case letters were significantly different $(P<0.05)$ between predator treatments.
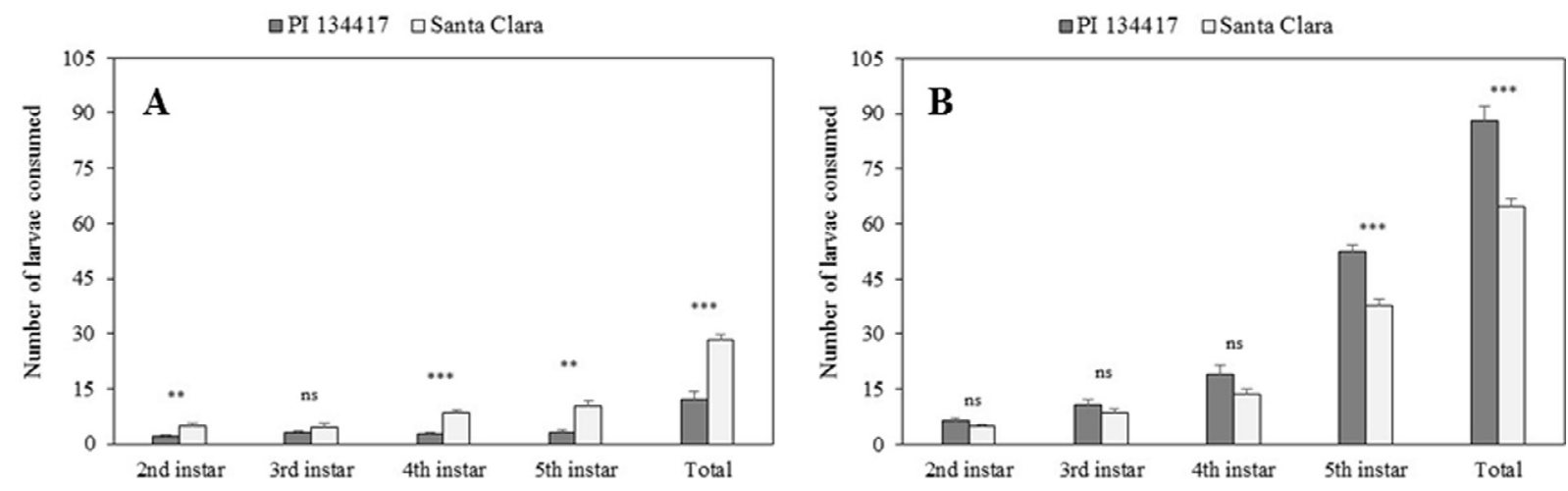

Fig. 4. Consumption of T. absoluta larvae by P. nigrispinus on resistant (PI 134417) and susceptible (Santa Clara) tomato plants with (A) and without (B) the plant present. ***, $P<0.001 ;{ }^{* *}, P<0.01$ 
both nymphal and adult $P$. nigrispinus treatments, and significantly fewer than those recovered from control plants (Fig. 5). Tomato genotype affected the number of live $T$. absoluta larvae recovered only in adult $P$. nigrispinus treatment, with greater numbers recovered from plants of the resistant genotype (Fig. 5). The release of either nymphs or adults reduced damaged leaf area by approximately one third (data not shown).

\section{Discussion}

The time required for $P$. nigrispinus nymphal development was neither directly (with plant) nor indirectly (without plant) affected by tomato genotype. However, $P$. nigrispinus adult longevity was extended by $66.1 \%$ and $33.5 \%$ when $T$. absoluta larvae were reared on Santa Clara plants with the plants present and absent, respectively. With plants present, nymphal survival to adult was substantially decreased with $T$. absoluta larvae on the resistant genotype, whereas without plants, survival rates were similar. In addition, $P$. nigrispinus adults lived longer with plants present than in their absence, especially with Santa Clara plants, suggesting that $P$. nigrispinus gain longevity by feeding on tomato plant tissues.

Podisus nigrispinus has evolved omnivorous adaptations that allow it to feed on both plant and animal food sources (Torres and Boyd, 2009), similar to other predatory mirids (Biondi et al., 2016). Plant feeding supplies necessary nutrients, steroids (Thummel and Chory, 2002), and water (Magalhães et al., 2015) thereby improving predator development (Oliveira et al., 2002; Evangelista Júnior et al., 2003, 2004). Our results indicate that Santa Clara plants were nutritionally superior to PI 134417 plants in supporting $P$. nigrispinus nymphal survival and adult longevity.

With plants present, more T. absoluta larvae were consumed by $P$. nigrispinus nymphs on susceptible plants than on resistant plants. Conversely, with plants absent, more T. absoluta larvae were consumed by $P$. nigrispinus nymphs if they developed on resistant plants than if they developed on susceptible ones. Independent of host plant type, an average of $73.5 \%$ more $T$. absoluta larvae were consumed by $P$. nigrispinus when plants were absent than when they were present. We observed that larvae of $T$. absoluta reared on resistant plants were visually smaller than larvae fed the susceptible genotype, although this was not quantified. Therefore, it appears likely that $P$. nigrispinus nymphs had to consume more leafminer larvae in the absence of plants to compensate for the lack of plant food.

Our results indicate that resistant PI 134417 plants directly impact $P$. nigrispinus performance as survival of the bugs was reduced only in the presence of resistant plants. With plants absent, there were also indirect effects of resistant plants on bug development which may be attributed to malnourishment of the T. absoluta larvae. Moreover, P. nigrispinus adult longevity was not as increased in the presence of resistant plants as it was in the presence of susceptible plants. We infer that the predator was either negatively affected by walking on resistant plants, which possess higher diversity and density of glandular leaf trichomes, or via ingestion of allelochemicals during plant feeding that were not present in susceptible plants.

Leaves of PI 134417 plants had twice as many glandular trichomes per unit leaf area on both abaxial and adaxial leaf surfaces than did leaves of Santa Clara plants. In addition, leaves of the resistant genotype possessed glandular trichomes of types I, IV, VI, and VII, whereas leaves of the susceptible genotype possessed only types VI and VII. Allelochemicals expressed by the type-IV glandular trichomes that were absent on Santa Clara leaves have been implicated in negative effects on other insects (Fancelli et al., 2005; Oliveira et al., 2012). Plants of many solanaceous plants possess these specialized glandular trichomes that often express metabolites toxic to herbivorous insects (Schilmiller et al., 2008; Weinhold and Balwin, 2011). Glandular trichomes of types I, IV, VI, and VII have been found to exude the compounds 2-tridecanone, 2-undecanone (methyl ketones), chlorogenic acid (phenolics), rutin, myricetin (flavonoids), and zingiberene (sesquiterpenes) (Lin et al., 1987; Juvik et al., 1988; Aragão et al., 2000b; Kim et al., 2014). Some of these compounds have been associated with tomato resistance to T. absoluta (Ecole et al., 1999; Oliveira et al., 2012). A higher density of glandular trichomes on tomato leaves would result in more exudate released on the leaf surface, which can trap small arthropods (Fancelli and Vendramim, 2002; Muigai et al., 2002; Maluf et al., 2007) and impair the performance of larger ones, as we observed with $P$. nigrispinus. Despite the glandular trichomes on leaves of resistant tomato plants impacting tomato leafminer, our results demonstrate they also constrain $P$. nigrispinus foraging. Overall, nymphs and adults of $P$. nigrispinus remained on resistant plants only half as long as they did on susceptible plants. Similarly, Vivan et al. (2002) inferred that increased plant pilosity and presence of allelochemicals negatively affected $P$. nigrispinus predation on resistant tomato plants.

Tomato leafminer damage was similar between plant types after $72 \mathrm{~h}$ of larval infestation, but decreased with releases of $P$. nigrispinus as a biocontrol agent. Differences in damage between tomato genotypes were not evident because $72 \mathrm{~h}$ is not sufficient time for PI 134417 resistance to affect the leafminer larvae. The antibiosis expressed by this genotype negatively affects survival and larval growth of T. absoluta (Bottega et al., 2015), effects unlikely to be evident until later in larval development. Leaf area injured by $T$. absoluta larvae on plants of tomato was similar when nymphs or adults of $P$. nigrispinus were released, and was reduced by one third relative to the control treatment without predators. Vivan et al. (2002) reported that $P$. nigrispinus nymphs and adults preyed on similar numbers of $T$. absoluta larvae in both the greenhouse and the laboratory, consistent with the results of our study. An average of $70 \%$ of $T$. absoluta larvae were recovered from control plants, regardless of plant type, whereas half this number were recovered when $P$. nigrispinus nymphs were released. When $P$. nigrispinus adults were released, only about $20 \%$ of $T$. absoluta larvae were recovered from susceptible plants, and more than twice that number from resistant plants, suggesting that the foraging behavior of $P$. nigrispinus adults was impeded on resistant plants.

The results of our study demonstrate that $P$. nigrispinus development and foraging behavior were negatively affected on T. absoluta-resistant tomato plants. Therefore, resistant tomato genotypes possessing high densities of glandular trichomes, especially of types I and IV, could be antagonistic to augmentation biological control with P. nigrispinus in the field. A follow-up study is warranted to compare the efficiency of $P$. nigrispinus releases in different numbers against $T$. absoluta on both resistant and susceptible tomato plants under greenhouse and field conditions. Additional research should assess the compatibility of $P$. nigrispinus with other environmentally safe control methods for improvement of tomato leafminer IPM.

\section{Author contribution}

ALBJ conceived and designed the study. DBB, NELR, and WIE conducted the experiment. BHSS and JCB analyzed data. DBB and BHSS wrote the manuscript.

\section{Acknowledgements}

Thanks to National Council for Scientific and Technological Development (Conselho Nacional de Desenvolvimento Científico 
e Tecnológico - Brazil, Process CNPq no. 553315/2010-2), for funding this research.

\section{References}

Abbes, K., Biondi, A., Kurtulus, A., Ricupero, M., Russo, A., Siscaro, G., Chermiti, B., Zappalà, L., 2015. Combined non-target effects of insecticide and high temperature on the parasitoid Bracon nigricans. PloS One 10, e0138411. http://dx.doi.org/10.1371/journal.pone.0138411.

Aragão, C.A., Dantas, B.F., Benites, F.R.G., 2000a. Tricomas foliares em tomateiro com teores contrastantes do aleloquímico 2-tridecanona. Sci. Agric. 57, 813-816.

Aragão, C.A., Maluf, W.R., Dantas, B.F., Gavilanes, M.L., Cardoso, M.G., 2000b. Tricomas foliares associados à resistência ao ácaro rajado (Tetranychus urticae Koch.) em linhagens de tomateiro com alto teor de 2-tridecanona nos folíolos. Cienc. Agrotec. 24, 81-93.

Baldin, E.L.L., Vendramim, J.D., Lourenção, A.L., 2005. Resistência de genótipos de tomateiro à mosca-branca Bemisia tabaci (Gennadius) biótipo B (Hemiptera: Aleyrodidae). Neotrop. Entomol. 34, 435-441.

Biondi, A., Zappalà, A., Stark, J.D., Desneux, N., 2013. Do biopesticides affect the demographic traits of a parasitoid wasp and its biocontrol services through sublethal effects? PloS One 8, e76548. http://dx.doi.org/10.1371/journal. pone.0076548.

Biondi, A., Zappalà, A., Mauro, A.D., Tropea Garzia, G., Russo, A., Desneux, N., Siscaro, G., 2016. Can alternative host plant and prey affect phytophagy and biological control by the zoophytophagous mirid Nesidiocoris tenuis? BioControl 61, 7990.

Bottega, D.B., Souza, B.H.S., Silva, A.G.Boiça., Júnior, A.L., 2014. Comportamento de Podisus nigrispinus (Dallas) (Hemiptera: Pentatomidae) na interação com lagartas de Spodoptera cosmioides (Walker) (Lepidoptera: Noctuidae) e cultivares de soja com diferentes graus de resistência. Rev. Agric. 89, 53-64.

Bottega, D.B., Boiça Júnior, A.L., Souza, B.H.S., Lourenção, A.L., 2015. Aspectos biológicos de Tuta absoluta (Lepidoptera: Gelechiidae) criada em folhas de diferentes genótipos de tomate. Rev. Ciênc. Agrár. 38, 139-148.

De Bortoli, S.A., Otuka, A.K., Vacari, A.M., Martins, M.I.G., Volpe, H.X.L., 2011. Comparative biology and production costs of Podisus nigrispinus (Hemiptera: Pentatomidae) when fed different types of prey. Biol. Control 58, 127-132.

De Clercq, P., 2000. Predaceous stinkbugs (Pentatomidae: Asopinae). In: Schaefer, C. W., Panizzi, C.R.C. (Eds.), Heteroptera of Economic Importance, pp. 737-789. FL, Boca Raton.

De Clercq, P., Mohaghegh, J., Tirry, L., 2000. Effect of host plant on the functional response of the predator Podisus nigrispinus (Heteroptera: Pentatomidae). Biol. Control 18, 65-70.

Desneux, N., Wajnberg, E., Wyckhuys, K.A.G., Burgio, G., Arpaia, S., NarváezVasquez, C.A., González-Cabrera, J., Ruescas, D.C., Tabone, E., Frandon, J., Pizzol J., Poncet, C., Cabello, T., Urbaneja, A., 2010. Biological invasion of European tomato crops by Tuta absoluta: ecology, geographic expansion and prospects for biological control. J. Pest Sci. 83, 197-215.

Desneux, N., Luna, M.G., Guillemaud, T., Urbaneja, A., 2011. The invasive South American tomato pinworm, Tuta absoluta, continues to spread in Afro-Eurasia and beyond: the new threat for tomato world production. J. Pest Sci. 84, $403-$ 408.

Ecole, C.C., Picanço, M., Jham, G.N., Guedes, R.N.C., 1999. Variability of Lycopersicon hirsutum $f$. typicum and possible compounds involved in its resistance to Tuta absoluta. Agric. For. Entomol. 1, 249-254.

Evangelista Júnior, W.S., Gondim Júnior, M.G.C., Torres, J.B., Marques, E.J., 2003. Efeito de plantas daninhas e do algodoeiro no desenvolvimento, reprodução e preferência para oviposição de Podisus nigrispinus (Dallas) (Heteroptera: Pentatomidae). Neotrop. Entomol. 32, 677-684.

Evangelista Júnior, W.S., Manoel, G.C., Gondim Júnior, M.G.C., Torres, J.B., Marques, E.J., 2004. Fitofagia de Podisus nigrispinus em algodoeiro e plantas daninhas. Pesqui. Agropecu. Bras. 39, 413-420.

Fancelli, M., Vendramim, J.D., 2002. Development of Bemisia tabaci (Gennadius, 1889 ) biotype B on Lycopersicon spp. genotypes. Sci. Agric. 59, 665-669.

Fancelli, M., Vendramim, J.D., Frighetto, R.T.S., Lourenção, A.L., 2005. Exsudado glandular de genótipos de tomateiro e desenvolvimento de Bemisia tabaci (Genn.) (Sternorrhyncha: Aleyrodidae) biótipo B. Neotrop. Entomol. 34, 659665.

Galdino, T.V.S., Picanço, M.C., Ferreira, D.O., Silva, G.A.R., Souza, T.C., Silva, G.A., 2015. Is the performance of a specialist herbivore affected by female choices and the adaptability of the offspring? PloS One 10, e0143389. http://dx.doi.org/ 10.1371/journal.pone.0143389.

Gentz, M.C., Murdoch, G., King, G.F., 2010. Tandem use of selective insecticides and natural enemies for effective, reduced-risk pest management. Biol. Control 52, 208-215.

Gonçalves, M.I.F., Maluf, W.R., Gomes, L.A.A., Barbosa, L.V., 1998. Variation of 2Tridecanone level in tomato plant leaflets and resistance to two mite species (Tetranychus sp.). Euphytica 104, 33-38.

Hensley, S.D., Hammond, A.M., 1968. Laboratory techniques for rearing the sugar cane borer on an artificial diet. J. Econ. Entomol. 61, 1742-1743.

Jesus, F.G., Boiça Júnior, A.L., Alves, G.C.S., Zanuncio, J.C., 2014. Behavior, development, and predation of Podisus nigrispinus (Hemiptera: Pentatomidae) on Spodoptera frugiperda (Lepidoptera: Noctuidae) fed transgenic and conventional cotton cultivars. Ann. Entomol. Soc. Am. 107, 606-616.

Juvik, J., Bakba, B., Timmermann, E., 1988. Influence of trichome exsudates from species of Lycopersicon on oviposition behavior of Helicoverpa zea Boddie. J. Chem. Ecol. 14, 1261-1287.

Kim, J., Matsuda, Y., Ning, J., Schilmiller, A.L., Hammar, D., Jones, A.D., Pichersky, E., Last, R.L., 2014. Analysis of natural and induced variation in tomato glandular trichome flavonoid identifies a gene not present in the reference genome. Plant Cell 26, 3272-3285.

Lin, S., Trumble, J., Kumamoto, J., 1987. Activity of volatile compounds in glandular trichomes of Lycopersicon species against two insect herbivores. J. Chem. Ecol. $13,837-849$.

Luckwill, L.C., 1943. The Genus Lycopersicon: An Historical, Biological, and Taxonomical Survey of the Wild and Cultivated Tomatoes. Aberdeen University Press, Aberdeen.

Magalhães, G.O., Vacari, A.M., Laurentis, V.L., De Bortoli, A.S., Polanczyk, R.A., 2015. Interactions of Bacillus thuringiensis bioinsecticides and the predatory stink bug Podisus nigrispinus to control Plutella xylostella. J. Appl. Entomol. 139, 123-133.

Maluf, W.R., Barbosa, L.V., Costa Santa-Cecília, L.V., 1997. 2-Tridecanone-mediated mechanisms of resistance to the South American tomato pinworm Scrobipalpuloides absoluta (Meyrick, 1917) (Lepidoptera-Gelechiidae) in Lycopersicon spp. Euphytica 93, 189-194.

Maluf, W.R., Inoue, I.F., Ferreira, R.P.D., Gomes, L.A.A., Castro, E.M., Cardoso, M.G., 2007. Higher glandular trichome density in tomato leaflets and repellence to spider mites. Pesqui. Agropecu. Bras. 42, 1227-1235.

Miranda, M.M.M., Picanço, M.C., Zanuncio, J.C., Guedes, R.N.C., 1998. Ecological life table of Tuta absoluta (Meyrick) (Lepidoptera: Gelechiidae). Biocontrol Sci. Technol. 8, 597-606.

Molina-Rugama, A.J., Zanuncio, J.C., Torres, J.B., Zanuncio, T.V., 1997. Longevidad y fecundidad de Podisus nigrispinus (Heteroptera: Pentatomidae) alimentado con Musca domestica (Diptera: Muscidae) y frijol. Rev. Biol. Trop. 45, 1125-1130.

Muigai, S.G., Schuster, D.J., Bassett, M.J., Scott, J.W., Mcauslane, H.J., 2002. Mechanisms of resistance in Lycopersicon germplasm to the whitefly Bemisia argentifolii. Phytoparasitica 30, 347-360.

Naselli, M., Urbaneja, A., Siscaro, G., Jaques, J.A., Zappalà, L., Flors, V., Pérez-Hedo, M., 2016. Stage-related defense response induction in tomato plants by Nesidiocoris tenuis. Int. J. Mol. Sci. 17, 1210. http://dx.doi.org/10.3390/ijms17081210.

Oliveira, J.E.M., Torres, J.B., Carrano-Moreira, A.F., Barros, R., 2002. Efeito das plantas do algodoeiro e do tomateiro, como complemento alimentar, no desenvolvimento e na reprodução do predador Podisus nigrispinus (Dallas) (Heteroptera: Pentatomidae). Neotrop. Entomol. 31, 101-108.

Oliveira, C.M., Andrade Júnior, V.C., Maluf, W.R., Neiva, I.P., Maciel, G.M., 2012. Resistência de linhagens de tomateiro à traça Tuta absoluta transmitido por aleloquímicos e densidade de tricomas. Cienc. Agrotec. 36, 45-52.

Opara, J., 2016. Surveillance critical to halting deadly tomato pest. <http://www. scidev.net/sub-saharan-africa/farming/news/surveillance-critical-haltingdeadly-tomato-pest.html/> (accessed 05.12.16).

Pérez-Hedo, M., Bouagga, S., Jaques, J.A., Flors, V., Urbaneja, A., 2015. Tomato plant responses to feeding behavior of three zoophytophagous predators (Heteroptera: Miridae). Biol. Control 86, 46-51.

Roditakis, E., Vasakis, E., Grispou, M., Stavrakaki, M., Nauen, R., Gravouil, M., Bassi, A., 2015. First report of Tuta absoluta resistance to diamide insecticides. J. Pest Sci. 88, 9-16.

Ruberson, J.R., Tauber, M.J., Tauber, C.A., 1986. Plant feeding by Podisus maculiventris (Hemiptera: Pentatomidae): effect on survival, development and preoviposition period. Environ. Entomol. 15, 894-897.

SAS Institute, 2008. User's Guide: Statistic Version 9.0. SAS Institute, Cary, NC, USA

Schilmiller, A.L., Last, R.L., Pichersky, E., 2008. Harnessing plant trichome for the production of useful compounds. Plant J. 54, 702-711.

Silva, G.A., Picanço, M.C., Bacci, L., Crespo, A.L.B., Rosado, J.F., Guedes, R.N.C., 2011. Control failure likelihood and spatial dependence of insecticide resistance in the tomato pinworm, Tuta absoluta. Pest Manage. Sci. 67, 913-920.

Siqueira, H.A.A., Guedes, R.N.C., Picanço, M.C., 2000. Insecticide resistance in populations of Tuta absoluta (Lepidoptera: Gelechiidae). Agric. For. Entomol. 2, $1-7$.

Siqueira, H.A.A., Guedes, R.N.C., Fragoso, D.B., Magalhães, L.C., 2001. Abamectin resistance and synergism in Brazilian populations of Tuta absoluta (Meyrick) (Lepidoptera: Gelechiidae). Int. J. Pest Manage. 47, 247-251.

Smith, C.M., 2005. Plant Resistance to Arthropods: Molecular and Conventional Approaches. Springer, Dordrecht.

Thummel, C.S., Chory, J., 2002. Steroid signaling in plants and insects-common themes, different pathways. Genes Dev. 16, 3113-3129.

Torres, J.B., Boyd, D.W., 2009. Zoophytophagy in predatory Hemiptera. Braz. Arch. Biol. Technol. 52, 1199-1208.

Tropea Garzia, G., Siscaro, G., Biondi, A., Zappalà, L., 2012. Tuta absoluta, a South American pest of tomato now in the EPPO region: biology, distribution and damage. EPPO Bull. 42, 205-210.

Vacari, A.M., De Bortoli, S.A., Torres, J.B., 2012. Relationship between predation by Podisus nigrispinus and developmental phase and density of its prey, Plutella xylostella. Entomol. Exp. Appl. 145, 30-37.

Valicente, F.H., O'Neil, R.J., 1995. Effect of host plants and feeding regimes on selected life history characteristics of Podisus maculiventris (Say) (Heteroptera: Pentatomidae). Biol. Control 5, 449-461. 
Vivan, L.M., Torres, J.B., Veiga, A.F.S.L., Zanuncio, J.C., 2002. Comportamento de predação e conversão alimentar de Podisus nigrispinus sobre a traça-dotomateiro. Pesqui. Agropecu. Bras. 37, 581-587.

Vivan, L.M., Torres, J.B., Veiga, A.F.S.L., 2003. Development and reproduction of a predatory stinkbug, Podisus nigrispinus in relation to two different prey types and environmental conditions. Biocontrol 48, 155-168.

Weinhold, A., Balwin, I.T., 2011. Trichome-derived O-acyl sugars are a first meal for caterpillars that tags them for predation. Proc. Natl. Acad. Sci. U.S.A. 108, 78557859.
Zanuncio, T.V., Batalha, V.C., Zanuncio, J.C., Santos, G.P., 1991. Parâmetros biológicos de Podisus connexivus (Hemiptera: Pentatomidae) em alimentação alternada com lagartas de Bombyx mori e larvas de Musca domestica. Rev. Arvore 15, 308 315.

Zanuncio, J.C., Freitas, F.A., Tavares, W.S., Lourenção, A.L., Zanuncio, T.V., Serrão, J.E. 2012. No direct effects of resistant soybean cultivar IAC-24 on Podisus nigrispinus (Heteroptera: Pentatomidae). Chil. J. Agric. Res. 72, 528-534. 